\title{
Religious Influence in Policy-Making: a Case of Sexual Education in Lithuania
}

\author{
Augustė Nalivaikè \\ Kaunas University of Technology \\ A. Mickevičiaus 37, LT-44244 Kaunas, Lithuania \\ cross'ref $^{\text {http://dx.doi.org/10.5755/j01.ppaa.19.1.25082 }}$
}

\begin{abstract}
The Lithuanian Ministry of Education adopted the sexual education and preparation for a family life policy in 2016. Policy formulation stage became the centre of the conflict between secular reproductive health and sex education activists and religious civil society organizations as well as Lithuanian Catholic Church which exerts its informal political power and utilizes institutional opportunity structures in various stages of policy-making. These groups clashed not only in the chambers of the Lithuanian Parliament but also in the media. Competing discourses were created and maintained in various public spaces. Non-governmental human rights organizations have tried to counter the discourse of oppositional conservative and religious political actors and actively participated in policy formulation. However, these attempts did not prevent the Ministry of Education from adopting a family and abstinence-oriented sex education, which favours specific religious values. This paper seeks to understand religious influence in sexual education policy formation in Lithuania. I utilize news media articles and anonymous in-depth interviews with various relevant actors involved. This case study also enriches theoretical literature on informal institutions, and institutional opportunity structures concerning religious actors influence morality policy-making.
\end{abstract}

Keywords: religion, qualitative, sexual education, influence, policy-making.

Raktažodžiai: religija, kokybinis tyrimas, lytinis švietimas, politikos formavimo procesas.

\section{Introduction}

The idea that religion and churches have an impact on political decision making is not recent. However, the questions regarding the role of religious actors in politics have been overlooked for some time due to the increased academic attention to the processes of societal modernization and secularization (Knill et al., 2014). Some researchers have predicted that the role of religion and churches in politics will lessen over time, but in some cases, it proved to be far more persistent than formerly expected.

Studies of religious influence in political decision making are mostly concentrated in one sphere of policy-making: morality policies. Religious organizations are observant of morality policymaking as this type of policy is related to values and beliefs and value conflicts in various societies. Values have fundamental significance in morality policies and church doctrines (Knill, 2003). Changes in certain societal values may threaten churches' power and actuality (Grzymala-Busse, 2016).

The research of morality policies has recently expanded (Mooney, 1999; Mucciaroni, 2011; Knill, 2013; Engeli et al., 2013; Heichel et al., 2013; Studlar and Burns, 2015; Budde et al., 2017). Regulation of reproductive rights, pornography, euthanasia, drugs, prostitution, same-sex partnerships and marriages are found in the sphere of morality policies and can be perceived as the attempts to determine a particular value system in the society (Mooney, 1999). The religious influence on abortion rights has been analysed to some extent (Minkenber, 2002; 2003; Szelewa, 2016; FormanRabinovici \& Sommer, 2018). 
I suggest that sexual education policy is also a type of morality policy for several reasons. First, the politics of youth sexuality are usually surrounded by discourse revolving around certain values and dos and don 'ts. Secondly, it is still somewhat controversial and inconvenient topic in many countries because it supposes so-called moral dilemmas. Lastly, research shows that religious actors are keen on participating in and try to influence this type of policy-making (Hodžić et al., 2012; Kuhar, 2015).

Sex education in public schools has become an important issue in recent years because of its importance to sexual health and well-being of young people. Both UNESCO (2009) and the World Health Organization (2010) initiated a universalized approach to sexual education, emphasizing its significance to young people. However, many national governments failed to adhere to these global recommendations (Hodžić et al., 2012). Research shows that in most countries where comprehensive sexual education was challenged, religious values played an important part (ibid.)

A systematic overview of sexuality education policies in various European countries revealed a diversity of approaches and implementation processes (Parker et al., 2009). Lithuania is defined as a country where sexual education is a controversial topic. There are several conservative and religious organizations which strongly oppose public sex education and use their influence in politics to stifle the efforts to implement science-based and comprehensive sexual education in schools (Lazarus, 2005).

In 2005 the Lithuanian Board of General Education authorized sexuality education guidelines; however, the working group responsible for them was mostly comprised of anti-choice Catholic organizations, and those guidelines were deemed to be too conservative. In 2004 the Catholic Church successfully blocked the youth health services and initiatives which would have helped to fill in some gaps in incompetent sexual education in Lithuania at the time (Hodžić et al., 2012).

The purpose of this paper is to analyze the Lithuanian Catholic Church's influence and role in the formation of sexual education policy in 2015 and 2016. The main interest is not the influence of various factors related to religion, for example, religiosity or religious freedoms, in politics, but how powerful the Catholic Church is in executing its political preferences in a given democratic regime. While the hierarchy of the Catholic Church and various satellite catholic civil society organizations participated in creating a particular public discourse about the alleged dangers of comprehensive sexual education mainly using various media channels, similarly to cases in other Central and Eastern European countries, this research examines the religious influence in the process of policy-making.

I argue that religious influence in policy-making processes in Lithuania can be explained using the concepts of institutional opportunity structures and informal institutions. First of all, I introduce the theoretical framework and briefly discuss the most recent academic literature. Secondly, the methodology and challenges related to qualitative elite interviews are presented. Then I explain the political and societal role of the Catholic church in Lithuania since 1990. Finally, the interview data is analysed and followed by conclusions.

\section{Informal institutions, institutional opportunity structures and religious influence in policy-making}

I hypothesise that most of this religious influence in policy-making in Lithuanian politics, including the adoption of sexuality policy which favours religious approach, has to do with informal political culture and informal institutions that are deeply embedded in the way the majority of the political actors understands political processes. The persistence and prevalence of informal rules and practices, in turn, create institutional and cultural opportunity structures which are utilized by the Catholic Church.

March and Olsen (2011) argue that institutions are certain sets of rules and organized practices which are embedded in a certain structure of meaning, and relatively resilient in relation to expectations of individuals and developing external circumstances. As North (1990, p. 3) puts it, institutions are the 'rules of the game' that shape the patterns and interactions that condition the 
relationships among individuals, and this also includes the political domain. Moreover, institutions are models that help individuals understand and anticipate how others will behave (North et al., 2006).

However, the academic definition of political institutions has proven to be a challenging task. So-called political 'rules of the game' include formal laws and social arrangements, informal norms and practices, as well as, shared perception about politics. The question then is not whether institutions matter but to what extent and through which processes institutions make a difference. This approach allows scientists to understand better how institutions organize political life, construct and deconstruct political authority, establish, exercise and redistribute power (March and Olsen, 2011). This is particularly important in policy-making when different stakeholders try to influence the outcomes.

Having this in mind, the analysis should not be limited to formal institutions and rules. As Levi (1990, p. 409) argues, 'the most effective institutional arrangements incorporate a normative system of informal and internalized rules'. Therefore, informal institutions deserve proper scholarly attention, as well. There has been a tendency to privilege formal institutions as 'rules of the game' (Mackay et al., 2010). According to Helmke and Levitsky (2004), such an attitude resulted in undertheorization and underestimation of research of informal political institutions.

What is more, research of formal institutions did not fully explain the dynamics of various political processes, including policy-making. Many so-called 'rules of the game' came from informal constraints that shaped political actors' behaviour in systematic and powerful ways. Therefore, more scholars have started to include informal rules, practices and networks into their research agendas (Helmke and Levitsky, 2003).

According to Helmke and Levitsky (2003), informal institutions should be differentiated not only from formal institutions, but also from other seemingly informal patterns like insufficient and weak institutions, cultural norms, and informal organizations. Therefore, they offer the following definition: 'informal institutions are socially shared rules, usually unwritten, that are created, communicated, and enforced outside of officially sanctioned channels.' (Helmke and Levitsky, 2003, p. 9), and by contrast, 'formal institutions are rules and procedures that are created, communicated and enforced through channels widely accepted as an official' (Helmke and Levitsky, 2004, p. 727). I would add that the rules should be shared politically to be considered informal political institutions.

Some scholars include religious and ideological beliefs, self-imposed modes of behaviour, traditions and even habits in their definition of informal institutions (Winiecki, 2004). Consequently, informal institutions are understood as some sort of legacy from the past and culture is emphasized as one of the key reasons for the prevalence of informality. The possibility for that to be true in some cases cannot be eliminated. However, Helmke and Levitsky (2004) argue that informal institutions are not path-dependency effects or cultural norms. Informal institutions constrain social, economic and political behaviour and occur in relation to formal ones. Therefore, they are "a nuanced phenomenon best examined at the intersection of institutional environments" (De Castro et al., 2014, p. 75).

The same-sex partnership legislation processes in Italy and Ireland, both states with large Catholic communities and strong Catholic Churches were examined by Knill \& Preidel (2015). Nevertheless, Ireland adopted legislation recognizing homosexual couples in tax, social and inheritance law sooner than Italy. These differences are attributed to states' different institutional settings that constrain or empower various actors in pursuing their interests in policy-making (Knill \& Preidel, 2015). In Italy, the strong fragmentation of executive power and lack of strong executive leadership resulted in access points for the Catholic Church as it was able to exploit such fragmentation. Active lobbying and close contacts between the politicians and church representatives also played a role. The authors call these circumstances and conditions 'institutional opportunity structures' (ibid.).

Minkenberg (2003, p. 196) also suggests that in some cases 'church-state relations represent an institutional arrangement which provides an 'opportunity structure' for religious interests in the political process and as such they determine to some extent whether churches, as political actors, 
operate as public institutions or as interest groups'. Consequently, permissive reforms regarding morality policies often face stagnation or delay when the Catholic Church employs cultural and institutional opportunity structures (Knill et al., 2014).

While the theoretical concept of informal institutions has not been previously applied (to the best of my knowledge) in the research of religious influence in policy-making, several researchers suggested analyzing the informal political power and access (Schmitt et al., 2013), or informal relationship between state and church (Budde et al., 2017), I argue that Helmke and Levitsky's (2003) definition is an analytically useful and novel approach to better understand the institutional and cultural opportunity structures allowing informal religious influence in policy-making. However, the historical dimension of informal institutions needs further examination, especially in the context of the post-communist past.

This paper contributes to the theoretical debate by helping identify various institutional opportunities and access points that are utilized by the Catholic Church in morality policy-making in Lithuania. When institutional access exists, conditions for informal religious influence are created and sustained. Similarly, informal institutions reinforce and sustain institutional access.

\section{Open-ended qualitative survey}

This case study is interested in 'the motivations and activity within the political process' (Lilleker, 2003, p. 207), specifically the processes and dynamics surrounding sexuality education policy-making, and qualitative in-depth elite and expert interviewing appears to be the right yet challenging methodological choice. Interviews allow scientists to examine the events which they know little about, the activities that happen behind the closed doors, the dynamics of the various political process, and relations between different actors. They enable researchers to learn nuanced information and examine various political phenomenon in-depth (Lilleker, 2003).

For these reasons, interviewing was chosen for this research. In recent years more researchers have started to discuss issues and challenges associated with elite interviewing in qualitative studies (Lancaster, 2017). The term 'elite' is used to describe individuals or groups of individuals who supposedly have closer proximity to power, knowledge or expertise (Morris, 2009) or policy-making (Lilleker, 2003). Mikecz (2012) argues that elites are distinguishable from non-elites because of their ability to influence people or events through social networks, structures and social capital.

It may be the right methodology; however, researchers talk about 'falling into a number of traps' (Harvey, 2011, p. 431) or 'navigating a potential minefield' (Lilleker, 2003, p. 2017). To gain insight into the informal religious influence in policy-making, the researcher must select interviewees carefully and make sure they have experience or expertise related to a research problem. The methodological issues in elite interviewing are challenging both regarding validity and reliability of data. The validity has to do with the appropriateness of the measuring instrument to the task, and reliability is related to the consistency of results if the measurement of data is repeated (Berry, 2002). Other challenges in interviewing revolve around the sample size of the interviews and the selection process of the interviewees. The broad sample is usually required to collect reliable and valid data, however, the quality of the interviews also depends on the content communicated during those interviews. To examine the nature of the individual political activity or learn what events took place and when, the researcher must ensure that all potential interviewees had equal access or opportunity to participate in the events in question (Lilleker, 2003). Significant challenges in interviewing elites are the difficulty of gaining access to them because there are specific barriers which separate them from the rest of society. What is more, political elites may manipulate important information or altogether deny access to it (Mikecz, 2012). Finally, "interviewers must always keep in mind that it is not the obligation of a subject to be objective and tell us the truth" (Berry, 2002, p. 680).

Anonymous, in-depth, semi-structured interviews with the political elite and comprehensive sexual education activists $(n=10)$ were chosen as the main method for collecting data. The respondents were chosen based on these criteria:

- An individual who was or is a crucial decision-maker. 
- An individual who had or has a significant influence on policymaking choices.

- An individual who was or is a firsthand witness to political decision making (Mikecz, 2012)

The main advantage of anonymous interviewing is, in theory, that on record high-level interviewees may speak more openly and willingly about the existence of various informal practices and religious influence that they have experienced or have been involved in rather than referring to stories about other people or organizations. Consequently, more reliable and subtle data is collected (Lašas, 2017). However, two politicians did not agree to record the interview, and notes were taken instead.

The type of interviewing in this study was of an open-ended nature and semi-structured. These types of interviews allow the researcher to ask key respondents for certain facts of the phenomenon studied as well as the respondents' opinions about certain events which may become the basis of the further investigation (Yin, 1984). The semi-structured interviews benefit the flexibility and adaptability of the interviews. On the other hand, some researchers advise caution and argue that elite interviewing is surrounded by a paradox: 'the valuable flexibility of open-ended questioning exacerbates the validity and reliability issues that are part and parcel of this approach' (Berry, 2002, p. 679). Interview data was supported by news media articles about the sexual education policymaking process in Lithuania.

\section{Sources of "institutional opportunity": the political role of the Catholic Church in Lithuania after 1990}

During the Soviet occupation of Lithuania, the Catholic Church has suffered from state repressions and anti-religious politics. Totalitarian regime wanted to integrate Lithuania into the social, legal and economic system of the Soviet Union, and it meant repressions against citizens and institutions. The Catholic Church, in some way, became the enemy 'number one' because many Lithuanians have associated the Church with patriotism and national culture which the regime wished to eradicate (Vitkauskas, 2000).

The Catholic Church suffered the most damage during the first years of the occupation: many churches and monasteries were closed, the real estate belonging to the Church was nationalized, the Church was burdened with high taxes, priests and members of the Catholic community were repressed and controlled (Čepaitienè, 2002). While later the relation between the Church and regime developed and somewhat stabilized, the Catholic Church's role in society was significantly reduced.

The Catholic Church has been formally re-introduced and re-established just after the 1990 Independence. Not only did the Church regain its status in the now democratic political regime, but it also got most of the lost properties back, the churches and monasteries continued their activities, theological education was introduced in schools soon after 1990 (Pruskus, 2003). It looks like the political elite at the time did not even consider changing the role and status of the highly esteemed Catholic Church in Lithuania. To understand this, one must examine the role of the Catholic Church in the resistance and independence movement.

While Huntington (1991) did not analyze the case of Lithuania separately, he regarded Protestant and Catholic churches' leaders essential in the third wave of democratization. The Catholic Church authorities in Lithuania were active participants in the independence movement as well as defenders of the rights of catholic citizens. It also succeeded in mobilizing thousands of Lithuanians (Streikus, 2002). The Catholic Church was a powerful opposition force even before Sajūdis, and after the formation of the independence movement, Catholic Church representatives were part of the Sajūdis Council and its groups across Lithuania (Pruskus, 2003).

However, the Church has not been just a passive observer of the democratization processes. During the first ten years after the Independence, it sought to actively participate in political life, gaining political power in the public sphere and sharing this power with other influential institutions (Ališauskienè \& Kuznecovienè, 2012).

In 1990 the Catholic Church had a prominent role in politics, sometimes even a distinctive role compared to other societal organizations. The Church actively endorsed certain politicians and 
political parties in municipality elections, participated in legislative processes related to the principle of religious freedom in Lithuania. In 1991 it eagerly took part in the legislation of the law of Education. In 1996 the Law on the National Radio and Television established that the Lithuanian Bishops' Conference (an official Catholic Church body in Lithuania) has a representative in the Council of the National Radio and Television of Lithuania while other religious communities' representatives do not have this right (Ališauskienė \& Kuznecovienė, 2012).

What is more, in 1990 some priests were the political candidates in the elections of the Supreme Council of the Republic of Lithuania and one priest was elected. Such direct political participation by the representatives of the Catholic church opened the discussions in the media about the ambiguous role and impact of the Church in politics (Pruskus, 2003). The Catholic church also maintained a close relationship with Democratic Labour Party of Lithuania (now non-existent) and Lithuanian Christian Democratic Party. However, in 1995 reports showed up in the media, criticizing these relationships (Ališauskienė \& Kuznecovienè, 2012).

Thirty years have passed since the Independence, and the Catholic Church is still an active participant of a country's social and political life. The role of the Catholic Church and religion in Lithuanian politics has been analyzed to some extent. However, the exact mechanisms and dynamics of religious influence in policy-making have not been examined in greater detail. Ališauskienė and Kuznecoviene (2012) analyzed the dynamics of the Catholic Church's participation in public life in 1990 - 2010, concluding that in Lithuania the Catholic Church has been very active in both political and societal participation. However, such active participation does not go unnoticed by media and some non-governmental organizations concerned with human rights issues, and therefore, becomes a debatable issue in society. When it comes to religiosity, most Lithuanians declare Catholicism as religious identity, but the numbers of church attendance and other religious practices are low. In academic literature, this has been explained using the concept of religious individualism (Ališauskienė \& Samuilova, 2011).

The regulation policy of religious communities has been analyzed in relation to Lithuania's treaties with the Holy See by Presniakovaite (2014). The author asks whether legal regulations performed via these international treaties between the Lithuanian state and the Catholic Church create discriminatory conditions in relation to other traditional religious communities. She concludes that while the treaty signed with Lithuania seems adequate to treaties signed between the Holy See and other states, in Lithuania's case these international agreements separate the Catholic Church from other religious communities because the treaties contain legal obligation by the state to finance catholic educational institutions, among them Catholic schools and schools preparing teachers of the catholic religion. The author concludes that the question of whether the treaties create discriminatory conditions to other religious communities remains open and debatable (Presniakovaite, 2014).

Public funding of religious communities in Lithuania is examined concerning social policymaking. Religious communities are considered to play an important part in social politics; therefore, the state creates direct subsidies and tax incentives that religious communities receive. The authors mention that according to the treaties with Holy See, the Catholic Church in Lithuania does not pay taxes. Moreover, free-will offerings for the Catholic Church are also exempted from taxation (Pivoras \& Presniakovaite, 2016).

Some researchers analyze the Catholic Church in Lithuania using religious hegemony theoretical framework. The Catholic Church has no competition with other religions in Lithuania, and, according to Schröder (2012), the main confrontation in Lithuanian society happens between the Church and secular values, which becomes clear when policy conflicts develop between the Church and secular nongovernmental organizations in the policy formation stage, for example, in working groups.

Lithuanian Constitution clearly separates church and state in Article 43 by stating "There shall be no state religion in Lithuania", and there is not. However, according to Minkenberg (2003, p. 197), "constitutions alone are rather misleading and inaccurate guides to political reality". They can be one of the sources specifying state-church relations, but the reality is much more complex (ibid.) While 
officially in Lithuania the state is separated from the Catholic Church, de facto it is a powerful and influential actor in politics, whose interests often shape political outcomes (Ališauskienè et al., 2012).

Religious hegemony theoretical framework can be combined with the notion that the Catholic Church in Lithuania has the moral authority and is highly regarded by some politicians (GrzymalaBusse, 2014). The relation between the Catholic Church and the state has been conceptualized using the theoretical framework of "moral authority" in many post-Communist states, and, according to Grzymala-Busse (2014), this conceptualization is related to "historical legacies" (p. 338). Such "historical legacies" in the academic literature on post-Communist states are connected to a fusion of national and religious identities which can also be called religious nationalism (Grzymala-Busse, 2016). As Grzymala-Busse (2014, p. 338) argues: "Where churches successfully fused national and religious identities, they gained a great deal of moral authority", and churches with moral authority gain institutional access to policymaking and influence.

The convergence of national and religious identities in Lithuania is explained as a legacy of the communist past. The Catholic Church and religion have been associated with national identity and preservation of Lithuanian language even before the 1944 Soviet re-occupation, and this partly explains the role that the Catholic Church had in the independence movement as well as in politics during the first years that followed the Independence (Streikus, 2002). Similar ideas are expressed about the Catholic Church in Poland (Szocik \& Szyja, 2015; Szelewa, 2016). The Catholic Church in Lithuania is still considered to be a moral authority in relation to policy-making, which creates institutional access and opportunities for informal religious influence and maintaining the status as an important social and religious actor in public life.

\section{The formal relation between the Catholic Church and the Lithuanian state}

The relation between the Lithuanian state and the Catholic church is formally regulated by these acts and laws:

- The Constitution of the Republic of Lithuania (1992)

- The Law on Religious Communities (1995)

- The Law on Education (2011)

- The Law on the National Radio and Television (1996)

- The treaties between the Holy See and the Republic of Lithuania (2000)

The treaties with the Holy See create certain formal institutional and financial privileges for the Catholic Church. According to the Article 1 of the agreement with the Holy See, the same conditions shall be created for teaching the Catholic religion in all state and municipal schools of general education as for teaching other subjects (the Holy See, 2000). Noteworthy, the Catholic religion, not the subject of religion in general. The Catholic religion as a subject at school is only mandatory in Catholic schools. In public schools, pupils can choose the Catholic religion or ethics.

Article 4 establishes that the state supports the activities of Catholic youth organizations and in doing so, provides these organizations with the possibilities to use the premises and resources of the state. Finally, Article 9 establishes that non-state and non-municipal Catholic educational institutions and state or municipal educational institutions established together with the Catholic church shall be financed from the state's budget to the same degree as state or municipal educational institutions (the Holy See, 2000). Therefore, co-operation in education essentially means that the state finances private Catholic educational institutions. What is more, these private Catholic educational institutions may charge parents wishing their kids to attend such institutions with additional educational fees.

The law on education further establishes privileges to private Catholic educational institutions. Article 10 states that the private educational institutions established by traditional religious communities are also guaranteed so-called 'environmental' funds provided by the state (The Law on Education, 2011). These 'environmental' funds cover the costs of administrative staff and office supplies, as well as heating, electricity and water expenses. Public state and municipal educational institutions are not guaranteed these funds and must compete for these financial resources. According 
to 2016 - 2017 data provided by the National Association of Catholic Schools in Lithuania, there are ten private Catholic educational institutions (as of 2018, one private Catholic school in Kaunas has been closed).

The formal relationship between the state and the Catholic church, including laws mentioned above, creates institutional access and opportunity structures for religious influence in politics. Institutional access is also easier to attain when the Catholic church is perceived as a moral authority regarding specific political questions.

\section{Using "institutional opportunity": ways of influencing sexual education policy}

The Minister of Education, Science and Sport signed the sexuality education and preparation for the family program in autumn 2016. This program was the result of heated discussions and debates within the working group created to prepare the document. The working group was reformed after the reports in the media appeared that it mainly consisted of the representatives of religious civil society organizations and Lithuania's Bishop Conference, while youth and human rights organizations were not even involved in the discussions. Several members of human rights and sexuality education advocacy organizations said that they did not even know that such a working group was formed and asked to be included (Tamkute, 2018).

In the end, representatives of 28 organizations participated in attempts to prepare the sexuality education program. They can be divided into four categories: catholic, conservative civil society organizations together with Lithuania's Bishop Conference (8); public servants from various government organizations (5); youth organizations (5); and human rights and sexuality education advocacy organizations (3). The representatives of the Ministry claimed that such a big number of participating organizations means that the Ministry is trying to hear everyone's ideas and concerns and reach a compromise that would benefit the recipients of this program - the youth (ibid.).

The agreement was almost impossible to reach because there was a clear ideological and value related division among the participants of the working group. The draft of the program was heavily criticized by the human rights and sexuality education advocacy organizations (Kluonis, 2015). Their science and WHO recommendations based arguments were overshadowed by catholic, conservative side, therefore, the human rights organizations expressed their concern by organizing a protest in front of the Ministry as well as got over 30 other civil society organizations to sign their official letter to then incumbent minister to create a sexual education program which is based on research and global recommendations (lrt.lt, 2016; manoteises.lt, 2016). The sexuality education policy was even called "the hostage of the church's interests" (Saulytè-Rindzevičè, 2016). The vice-minister said that the Ministry pays attention to the Church's opinion because "it protects the values" (lrt.lt, 2016).

The anonymous interview data reveals that there are several ways that the Catholic Church and its main organizational body - Lithuania's Bishops Conference - try to influence political decision making, including the policy-making of sexual education:

1.The formation of working groups. Five respondents suggested that the process of the formation of the working group is not transparent. It is not clear why some people and organizations are invited to contribute to a specific policy, especially when it comes to morality policies. However, according to these interviewees, the representatives of the Catholic Church are usually invited (R1, R6, R8, R9, R10). According to one interviewee, "the question really is whether equal opportunities exist to participate in working groups. No, they do not exist. However, the Lithuanian Bishop's Conference is always consulted. The question is how the Lithuanian Bishop's Conference gets to participate in the first place because the creation of working groups is not transparent." (R1) Indeed, the formation of working groups is not defined clearly in the law. Therefore, it is usually up to the certain higher-level public servant to form the group. In this case, the Catholic Church has a possibility to utilize two forms of influence: institutional opportunity structures (formation of the working group) and use the perception that the Church is a moral authority in these matters. I also interpret those invitations of the Catholic Church's representatives as part of informal political culture, meaning that inviting them is part of informal "rules of the game". 
2.Church's satellite civil society organizations (Kuhar, 2015). Church's position and message in the working group were strengthened by so-called satellite civil society organizations. In the case of the sexuality policy formation process, several religious, catholic civil society organizations (Lithuanian Parents' Forum, Western Lithuanian Parents' Forum, National Families' and Parents' Association, Ateitininkai Federation) worked along with Lithuania's Bishops Conference during the working group stage. Religious civil society organizations dominated the first working group, and only after other stakeholders insisted, the working group was reformed and included human rights organizations. As one respondent put it: "If you looked at the participants of the working group for sexual education, you would see that the majority of them were somehow related to the Catholic Church and it is suspicious" (R10). According to another interviewee (R9), "the political participation of these satellite organizations in working groups became more prominent around 2016-2017. Some politicians and these organizations are very close." These same organizations are also invited to other morality related working groups and policy-making processes to represent religious interests (R1, R6, $\mathrm{R} 8, \mathrm{R} 9, \mathrm{R} 10)$. It is not always clear who invites them, but some respondents believe there is a list of people that working group organizers are aware they should always invite if the issues at hand fall under the Catholic Church's interests (R9, R10). Satellite civil society organizations and their involvement in policy-making during working group stage create another institutional opportunity structure for the Church. Informal political institutions also manifest in this stage if some people and organizations are invited to participate based on shared understanding "of the rules of the game" and communication outside of the official channels.

3. Meetings between high-level politicians and church representatives. Four respondents mentioned that they witnessed meetings or themselves met with the highest level of church hierarchs for the purposes of consultation or helped regarding various national policies, including the questions of education (R2, R3, R4, R5). Several respondents suggested that the Catholic Church is one of the most influential organizations not only in Lithuania but also globally (R2, R4). These meetings show that the Catholic Church is perceived as a moral authority, and its opinion is highly regarded, and political power acknowledged among certain politicians. It means that the meetings can be understood as a part informal communication surrounding state-church relations in Lithuania. This, in turn, creates institutional and cultural opportunity structures for religious influence in policy-making.

\section{Conclusions}

This article examined the religious influence in the sexual education policy-making process in 2015 - 2016. The Catholic Church's influence in sexuality education policy-making can be differentiated into three spheres. First, the Church utilized the institutional opportunity structures when it was invited to be a part of and contribute to a working group formed specifically to address sexuality education issues in Lithuania. These institutional opportunity structures are created and can be utilized because the Catholic Church is regarded as a moral authority by many Lithuanian politicians. Second, Church's position in politics and the case of sexuality policy formation was strengthened by so-called religious satellite civil society organizations which also represented catholic values, and by doing so, creating an impression that this is what civil society favours. They also significantly strengthen the Catholic church's position in political discussions revolving morality policies.

Lastly, high-level politicians met and consulted with the representatives of the Catholic Church, which can be interpreted as a symptom of informal political culture and institutions. These three influence spheres revealed by the interview data show that the Catholic Church managed to incorporate its political preferences into the sexuality education and preparation for family program accepted in 2016.

\section{References}

1. Ališauskienè, M. \& Kuznecovienė, J. (2012). Katalikų bažnyčios vaidmuo viešajame Lietuvos gyvenime: dalyvavimo formų kaita. Filosofija, Sociologija. 23(2), 102 - 110. 
2. Ališauskienė, M. \& Samuilova, I. (2011). Modernizacija ir religija sovietinejje ir posovietinëje Lietuvoje. Kultūra ir visuomenè, 2(3), $67-81$.

3. Berry, J. M. (2002). Validity and Reliability Issues in Elite Interviewing. PS: Political Science and Politics. 35(4), $679-682$.

4. Budde, E.T. et al. (2017). A matter of timing: The religious factor and morality policies. Governance, 31(1), $45-63$.

5. Čepaitienè, R. (2002). Vilniaus bažnyčiu likimas sovietmečiu (1944-1990). Liaudies kultūra, $86(5), 32-38$.

6. De Castro, J. O., Khavul, S. \& bruton, G. D. (2014). Shades of Grey: How do Informal Firms Navigate Between Macro and Meso Institutional Environments? Strategic Entrepreneurship Journal, 8, $75-94$.

7. Engeli, I., Green-Pedersen C. \& Larsen L.T. (2013). The puzzle of permissiveness: understanding policy processes concerning morality issues. Journal of European Public Policy, 20 (3), 335 - 352.

8. Esquivel, J. C. (2016). Religion and Politics in Argentina: Religious Influence on Legislative Decisions on Sexual and Reproductive Rights. Latin American Perspectives, 208(43), 133 143.

9. Forman-Rabinovici, A. \& Sommer, U. (2018). An impediment to gender Equality?: Religion's influence on development and reproductive policy. World Development, 105, 48 -58 .

10. Grzymala-Busse, A. (2014). Thy Will Be Done? Religious Nationalism and Its Effects in East Central Europe. East European Politics and Societies and Cultures, 29(2), 338 - 351.

11. Grzymala-Busse, A. (2016). Weapons of the Meek: How Churches Influence Policy. World Politics, 68(1), $1-36$.

12. Harvey, W. S. (2011). Strategies for conducting elite interviews. Qualitative Research, 11(4), $431-441$.

13. Heichel, S., Knill, C. \& Schmitt, S. (2013). Public policy meets morality: conceptual and theoretical challenges in the analysis of morality policy change. Journal of European Public Policy. 20 (3), 318 - 334.

14. Helmke, G. \& Levitsky S. (2004). Informal Institutions and Comparative Politics: A Research Agenda. Perspectives on Politics, 2(4), 725-740.

15. Helmke, G. \& Levitsky, S. (2003). Informal Institutions and Comparative Politics: A Research Agenda. Working Paper \#307, Kellogg Institute.

16. Hodžić, et al. (2012). The politics of youth sexuality: Civil society and school-based sex education in Croatia. Sexualities, 15(3/4), $494-514$.

17. Huntington, S. P. (1991). The Third Wave: Democratization in the late twentieth century. Norman: University of Oklahoma Press.

18. Kaminskienè, G. (2015). Iš lytinio ugdymo - vis dar tik šnipštas. https://lsveikata.lt/sveikavisuomene/is-lytinio-ugdymo-vis-dar-tik-snipstas-3438 [2019 12 15]

19. Kluonis, M. (2015). Lytinis švietimas: moksleiviai bus vertinami, kaip yra pasirengę santuokai? https://manoteises.lt/straipsnis/lytinis-svietimas-moksleiviai-bus-vertinami-kaipyra-pasirenge-santuokai/

20. Knill, C. \& Preidel, C. (2015). Institutional opportunity structures and the Catholic Church: explaining variation in the regulation of same-sex partnerships in Ireland and Italy. Journal of European Public Policy, 22(3), 374 - 390.

21. Knill, C. (2013). The study of morality policy: analytical implications from a public policy perspective. Journal of European Public Policy, 20(3), 309 - 317.

22. Knill, C., Preidel, C. \& Nebel, K. (2014). Brake rather than Barrier: The Impact of the Catholic Church on Morality Policies in Western Europe. Western European Politics, 37(5), 845 - 866. 
23. Kuhar, R. (2015). Playing with science: Sexual citizenship and the Roman Catholic Church counter-narratives in Slovenia and Croatia. Women's Studies International Forum, 49, 84 92.

24. Lancaster, K. (2017). Confidentiality, anonimity and power relations in elite interviewing: conducting qualitative policy research in a politicised domain. International Journal of Social Research Methodology, 20(1), 93 - 103.

25. Lašas, A. (2017). Behind the storefront of democracy: The case of media-politics relations in Lithuania. Journalism, $1-18$.

26. Lazarus, J. V. (2005). Sex, lies and Lithuania: A misinformation campaign by antichoice advocates threatens common sense health reforms in Lithuania. Conscience, 16(1), 27 - 28.

27. Levi, M. (1990) A logic of institutional change. In: Cook KS and Levi M (eds) The Limits of Rationality. Chicago, IL: University of Chicago Press.

28. Lilleker, D. G. (2003). Interviewing the Political Elite: Navigating a Potential Minefield. Politics, 23(3), $207-214$.

29. LRT TV naujienų tarnyba (2016). Vyko protestas dèl lytinio švietimo programos. https://www.lrt.lt/naujienos/lietuvoje/2/144502/vyko-protestas-del-lytinio-svietimoprogramos

30. Mackay, F., Kenny, M. \& Chappel, L. (2010). New Institutionalism Through a Gender Lens: Towards a Feminist Institutionalism? International Political Science Review, 31(5), 573 588.

31. March, J. G. \& Olsen, J. P. (2011). Elaborating the "New Institutionalism" In: Goodin, R. E (ed) The Oxford Handbook of Political Science, Oxford: Oxford University Press.

32. Mikecz, R. (2012). Intervewing Elites: Addressing Methodological Issues. Qualitative Inquiry, 18(6), $482-493$.

33. Minkenberg, M. (2002). Religion and Public Policy: Institutional, Cultural and Political Impact on the Shaping of Abortion Policies in Western Democracies. Comparative Political Studies, 35(2), $221-247$.

34. Minkenberg, M. (2003). The Policy Impact of Church - State Relations: Family Policy and Abortion in Britain, France and Germany. Western European Politics, 26(1), 195 - 217.

35. Mooney, C. Z. (1999). The Politics of Morality Policy: symposium's editor's introduction. Policy Studies Journal, 27, $675-680$.

36. Morris, Z. S. (2009). The truth about interviewing elites. Politics, 29(3), $209-217$.

37. Mucciaroni, G. (2011). Are debates about 'morality policy' really about morality? Framing opposition to gay and lesbian rights. Policy Studies Journal, 39(2), $187-216$.

38. National Association of Catholic Schools https://sites.google.com/site/kasociacija/nariai [2019 12 10]

39. North, D. C. (1990). Institutions, Institutional Change and Economic Performance. Cambridge: Cambridge University Press.

40. North, D. C., Weingast B. R., \& Wallis J. J. (2006). A Conceptual Framework for Interpreting Recorded Human History. NBER Working Paper, No. 12795, 1 - 80.

41. Parker, R., Wellings, K., \& Lazarus J. V. (2009). Sexuality education in Europe: an overview of current policies. Sex Education, 9(3), $227-242$.

42. Per 30 nevyriausybinių organizaciju ragina ŠMM peržiūrèti rengiamą lytiškumo ugdymo programą (2016). https://www.15min.lt/naujiena/aktualu/lietuva/per-30-nevyriausybiniuorganizaciju-ragina-smm-perziureti-rengiama-lytiskumo-ugdymo-programa-56-625237

43. Pivoras, S. \& Presniakovaitè, K. (2016). Viešoji politika religinių bendruomenių atžvilgiu: tiesioginių subsidijų bei mokesčių lengvatų instrumentai Lietuvoje ir Latvijoje. Viešoji politika ir administravimas, 15(2), $235-250$.

44. Presniakovaite, K. (2014). Religinių bendruomenių reguliavimo politika: Lietuvos sutartys (2000-2012) su Šventuoju Sostu (Vatikanu). Politikos mokslų almanachas, 16, 79 - 99. 
45. Pruskus, V. (2003). Katalikų bažnyčios kaita Lietuvoje transformacijų laikotarpiu. Problemos, $63,45-61$.

46. Saulytė-Rindzevičè, K. (2016). Lytinis ugdymas - bažnyčios interesų ịkaitas. https://manoteises.lt/straipsnis/esmeralda-kuliesyte-lytinis-ugdymas/

47. Schröder, I. W. (2012). Hegemony and the Catholic church in Post-Soviet Lithuania. In. Kuznecovienė, J., Ališauskienè, M., Glodenis, D., \& Schröder, I. W. (sud.). Religija Lietuvoje: tarp sekuliarizacijos ir (ar) kaitos. p. p. 110 - 124. Kaunas: Vytautas Magnus University.

48. Streikus, A. (2002). Sovietų valdžios antibažnytinė politika Lietuvoje (1944-1990). Vilnius: Lietuvos gyventojų genocido ir rezistencijos tyrimo centras.

49. Studlar, D.T. \& Burns, G.J. (2015). Toward the permissive society? Morality policy agendas and policy directions in Western democracies. Policy Sciences, 48(3), 273 - 291.

50. Szelewa, D. (2016). Killing 'Unborn Children'? The Catholic Church and Abortion Law in Poland Since 1989. Social \& Legal Studies, 25(6), $741-764$.

51. Szocik, K. \& Szyja, A. (2015). Poland: A Dark Side of Church Cultural Policy. Studia Humana, 4(4), $13-22$.

52. Tamkute, K. (2018). Lytinio ugdymo programą rengusi darbo grupé - kompromisas aistroms nugesinti https://naujienos.alfa.lt/leidinys/iq/kompromisas-aistroms-nugesinti/

53. The Constitution of the Republic of Lithuania http://www3.lrs.lt/home/Konstitucija/Constitution.htm [2019 12 08]

54. The Law on https://eseimas.lrs.lt/portal/legalAct/lt/TAD/TAIS.395105/ZPzOxUEnvH [2019 12 09]

55. The treaties between the Holy See and Lithuanian state (2000) http://www.lcn.lt/en/bl/ssostas/sutartys/ [2019 12 08]

56. UNESCO. (2009). International Guidelines on Sexuality Education: An Evidence Informed Approach to Effective Sex Relationships and HIV/STI Education. Paris: UNESCO. Available at: http://www.hivpolicy.org/Library/HPP001617.pdf

57. Vitkauskas, V. (2000). Lietuvos Katalikų bažnyčios dvasininkų verbavimas NKVD/KGB agentais sovietmečiu. Lietuvos Katalikų mokslo akademijos metraštis, 16, 237 - 258.

58. WHO. (2010). Standards for Sexuality Education in Europe. Cologne: WHO Regional Office for Europe and Federal Centre for Health Education. Available at: https://www.bzgawhocc.de/fileadmin/user_upload/WHO_BZgA_Standards_English.pdf

59. Winiecki, J. (2004). Determinants of catching Up or Falling Behind: Interaction of Formal and Informal Institutions. Post-Communist Economies, 16(2), 137 - 152.

60. Yin, R. K. (1984). Case study research: design and methods. Beverly Hills, Calif.: Sage.

Augustė Nalivaikè

\section{Religijos įtaka politikos formavimo procesuose: lytinio švietimo Lietuvoje atvejis}

\section{Anotacija}

2016 m. Lietuvos Respublikos Švietimo ministerija prièmė ilgai lauktą sveikatos ir lytiškumo ugdymo bei rengimo šeimai programą. Šios programos formavimo procesą galima pavadinti ,mūšio lauku“, kuriame susidūrè pasaulietiškos, mokslu grịstu lytinio švietimo aktyvistų pilietinès organizacijos ir katalikiškos pakraipos pilietinès organizacijos bei Lietuvos Katalikų bažnyčios atstovai, kurie pasinaudojo neformalia ịtaka bei institucinèmis galimybėmis įvairiose politikos formavimo stadijose. Darbo grupèje, skirtoje šios programos kūrimui, retai sekèsi pasiekti kompromisą. Nors nevyriausybinès žmogaus teisių ir lytinio švietimo advokacijos organizacijos aktyviai dalyvavo tiek darbo grupès veikloje, tiek kuriant diskursą žiniasklaidoje, Švietimo ministerija prièmė katalikiškoms vertybėms palankią lytiškumo ugdymo programą. Šio straipsnio 
tikslas - pasitelkiant anonimiškus kokybinius interviu su tiesiogiai susijusiais asmenimis, atskleisti Katalikų bažnyčios ịtaką lytiškumo programos kūrimo procese. Pranešimai žiniasklaidoje šia tema naudojami, siekiant papildyti ir validuoti interviu duomenis. Ši atvejo analize taip pat papildo neformalios politinès kultūros ir institucinių galimybių moralès politikos formavimo procesuose literatūrą.

Auguste Nalivaiké - socialinių mokslų doktorantè, Kauno technikos universitetas, Lietuva email: auguste.nalivaikse@ktu.lt

Auguste Nalivaike - doctoral candidate in social science, Kaunas University of technology, Lithuania email: auguste.nalivaikse@ktu.lt 